\title{
Ryegrass endophyte and sheep reproduction
}

\author{
J.P.J. EERENS ${ }^{1}$, K.B. MILLER', J.G.H. WHITE*, H.S. EASTON ${ }^{3}$ and R.J. LUCAS ${ }^{2}$ \\ ${ }^{1}$ AgResearch, Private Bag 50022, Gore \\ ${ }^{2}$ Plant Science Department, PO Box 84, Lincoln University, Canterbury \\ ${ }^{3}$ AgResearch, Private Bag 11008, Palmerston North
}

\section{Abstract}

The influence of perennial ryegrass endophyte on sheep reproduction and early lamb growth was studied in a 3-year grazing experiment at the AgResearch regional station at Gore $\left(46^{\circ} 07^{\prime} \mathrm{S}\right.$, $\left.168^{\circ} 54^{\prime} \mathrm{E}\right)$. The trial consisted of 8 paddocks sown in endophyte-infected $(+\mathrm{E})$ or endophyte-free $(-\mathrm{E})$ Grasslands Nui perennial ryegrass, with $(+\mathrm{C})$ or without Grasslands Huia white clover. Endophyteinfected ryegrass delayed the lamb drop and reduced lamb weight gains during the lactation period. Lamb drop was delayed by an average of 3-5 days especially in the presence of clover. This may be due to an extended gestation period or delayed mating. There was no effect of endophyte on lamb birth weight, ewe conception rate and liveweight changes over autumn, winter and spring.

Keywords: Acremonium lolii, lambing time, liveweight change, Lolium perenne, sheep reproduction, Southland

\section{Introduction}

Since Fletcher \& Harvey (1981) showed that there was an association between ryegrass staggers and an endophytic fungus (Acremonium lolii) in perennial ryegrass (Lolium perenne), a large number of pastoral and animal factors associated with ryegrass pastures have been found to be affected by the presence of this endophyte. These include such disparate but well documented effects as a reduced whiteclover (Trifolium repens) component in endophyte-infected pastures (Sutherland \& Hoglund 1989; Stevens \& Hickey 1990), resistance to the Argentine stem weevil (ASW) (Listronotus bonariensis) (Prestidge et al. 1982) and increased pasture production (Latch et al. 1985). Research by Eerens et al. (1992), however, showed no endophyte effect on companion clover and slightly better pasture production in the absence of endophyte, in a cool environment where ASW causes negligible damage to endophyte free pastures.

Endophyte effects on animals, like ryegrass staggers (Fletcher \& Harvey 1981), reduced liveweight gain
(Fletcher 1983), increased body temperature (Fletcher 1993) and increased faecal moisture (Pownall et al. 1993) have also been well documented.

A similar fungus/grass association can be found in the USA where an endophytic'fungus (A. coenophiafum) of tall fescue (Festuca arundinacea) has comparable effects on pasture plants and animals. An important endophyte effect in the USA, reviewed by Schmidt \& Osbom (1993), concerns animal reproduction. Cattle and horses are reported to have reduced conception rates, extended gestation periods, increased calf and foal birth weight and increased complications at parturition related to the grazing of endophyte-infected tall fescue. No effects on reproduction due to the ryegrass endophyte have been reported.

The general perception in New Zealand is that the ryegrass endophyte does have a negative effect on sheep reproduction. Owing to difficulties in maintaining endophyte-free pastures in most areas of New Zealand, and especially in areas experiencing the worst endophyte-related problems, conclusive research has not yet been carried out. This paper reports sheep reproductive performance from a 3-year investigation of the effects of ryegrass endophyte.

\section{$M$ aterials and methods}

Eight pastures were established at the Gore Research Station in spring 1989. Two lines of Grasslands Nui perennial ryegrass (Lolium perenne) with either $70 \%$ $(+\mathrm{E})$ or $0 \%(-\mathrm{E})$ endophyte infection were used in combination with $(+\mathrm{C})$ or without Grasslands Huia white clover (Trifolium repens) $(+\mathrm{E}+\mathrm{C},-\mathrm{E}+\mathrm{C}$ and $+\mathrm{E},-\mathrm{E})$. The experimental design was-2 endophyte $\mathrm{x}$-2 clover $\mathrm{X}$ 2 replications. General management of the experiment has been reported in an earlier paper (Eerens $\boldsymbol{e t} \boldsymbol{a l}$. 1992) and only relevant ewe management practices are reported here.

Ewes stocked at 20/ha were split into 8 mobs in January of each year and remained on either endophyteinfected or endophyte-free pastures until the following January. From January to February/March the ewes grazed behind lambs. Target herbage on offer for ewes was $1200-1500 \mathrm{~kg} \mathrm{DM} / \mathrm{ha}$, while target herbage residue was $800-1000 \mathrm{~kg} \mathrm{DM} / \mathrm{ha}$. The ewes were flushed on fresh regrowth for 4-6 weeks after the lambs had been 
drafted off the trial. The ewes were then grouped into two mobs, based on the endophyte status of the pasture and mated to Coopworth rams. Two rams were used and they were inter-changed between the mobs twice weekly.

Over winter the ewes were kept in these mobs to facilitate management. Winter feed consisted solely of autumnsaved pasture and some regrowth. The clover component of the pastures over winter was low. Clover growth rates dropped to $<1 \mathrm{~kg} \mathrm{DM} / \mathrm{ha} /$ day in June and July (Eerens et $a l$. unpubl. data) and so any clover effect on the ewes was considered to be small.

The ewes were vaccinated (Coopers Multiline $\left.{ }^{(}\right)$, received a pre-lamb crutch and were returned to their original 8 paddocks one week before the expected start of lambing. Ewe liveweights were monitored all year round with weighings taking place at the start of flushing (March), pre-lambing (August), tailing (October), weaning (December) and at suitable times over winter. At birth, the number of lambs per ewe was recorded, as were birth weight, sex of the lambs and the date. These measurements were taken as quickly after birth as practicable. Measurements were also made on stillborn lambs and those dying shortly after birth. Lambs were regularly weighed to provide growth rate data over the ewe lactation period.

Data analysis was based on mob means of a 2 by 2 factorial experiment with 2 replications and replicated 3 years.

\section{Results}

\section{Weather information}

The daily air temperature at the Gore site ranged from a mean of $4.8^{\circ} \mathrm{C}$ in June to $14.1^{\circ} \mathrm{C}$ in February, with extreme temperatures of about $30^{\circ} \mathrm{C}$ and $-10^{\circ} \mathrm{C}$. Mean annual rainfall was $950 \mathrm{~mm}$ falling evenly throughout the year. No major deviations from the long-term averages were observed during the experiment.

\section{Animal measurements}

Ewe liveweight patterns averaged over the three years of the trial are given in Figure 1. Weight increases over the flushing period tended to be similar for all treatments. Ewes grazing the $+\mathrm{E}$ and $\mathrm{E}+\mathrm{C}$ pastures had the greatest weight losses from pre-lambing to tailing, but these were not significantly different from those grazing $-\mathbf{E}+\mathbf{C}$ and $-\mathrm{E}$ pastures. Weight gains from tailing to weaning were highest on the $-\mathrm{E}+\mathrm{C}$ and $+\mathrm{E}+\mathrm{C}$ treatments, with a slight weight reduction on the $+\mathrm{E}$ treatment.

Lambing was 3-5 days earlier (Table 1) on the $-\mathrm{E}+\mathrm{C}$ than on $+\mathrm{E}+\mathrm{C}$ and $+\mathrm{E}$ pastures and also on $-\mathrm{E}$ in comparison to $+\mathrm{E}+\mathrm{C}$. The influence of the eweweights and weight changes at different times before lambing on lambing date was examined and appeared to have no influence on lambing date. Neither did they appear to have an influence on lamb birth weight and ewe conception rates.

Table 1 The effect of 4 pasture treatments on lambing date, lamb birth weight and ewe conception rate (means over 3 years).

\begin{tabular}{lccc}
\hline & $\begin{array}{c}\text { Birth Weight } \\
(\mathrm{kg})\end{array}$ & $\begin{array}{c}\text { Ewe conception } \\
\text { rate }(\%)\end{array}$ & $\begin{array}{c}\text { Date of } \\
\text { Birth' }\end{array}$ \\
\hline$\left.-E+C^{* *}\right)$ & 4.44 & 187 & 7.9 \\
$+\mathrm{E}+\mathrm{C}$ & 4.58 & 192 & 12.5 \\
$-\mathrm{E}$ & 4.43 & 191 & 9.5 \\
$+\mathrm{E}$ & 4.35 & 196 & 10.5 \\
LSD $(5 \%)$ & 0.232 & 19.7 & 2.52 \\
\hline
\end{tabular}

' average number of days after 1 September for all lambs on the treatment to drop

- $E+C=$ endophyte-free + clover

$+\dot{E}+C=$ endophyte-infected + clover

$-E=$ endophyte-free

$+E=$ endophyte-infected

Lamb growth rates during the lactation period are represented in Figure 2. Lamb weights at both tailing 
(Oct) and weaning (Dec), were both highest for lambs grazing the $-\mathrm{E}+\mathrm{C}$ pastures followed by lambs grazing $+\mathrm{E}+\mathrm{C}$ and $-\mathrm{E}$ pastures with lambs grazing $+\mathrm{E}$ pastures having the lowest weights at those times.

Lamb birth weights (Table 1) were higher on the $+\mathrm{E}+\mathrm{C}$ than on the $-\mathrm{E}+\mathrm{C}$ and -E pastures, and lowest on $+\mathrm{E}$ pastures, none of the differences were significant.

Ewe conception rates (Table 1) were slightly higher on the $+\mathrm{E}$ and $+\mathrm{E}+\mathrm{C}$ pastures than on $-\mathrm{E}$ and $-\mathrm{E}+\mathrm{C}$ pastures, but again the differences were not significant.

\section{Discussion}

Southern New Zealand is unique in that endophyte-free pastures remain productive and free of endophyte for long periods (Widdup \& Ryan 1992). The longevity of endophyte-free pastures is probably due to low populations of ASW. Animal trials investigating a range of endophyte effects can therefore be carried out without special measures to protect the endophyte-free pastures from ASW attack. An earlier paper reported that although endophyte effects on pasture parameters were small, a measurable reduction in lamb weight gains was observed on endophyte-infected pasture in the presence

\section{- of ${ }^{-}$white $^{-}$clover-(Eerens- $^{-}$- $^{-}$al. 1992$)$-This- ${ }^{-}{ }^{-}{ }^{-a l s o}$} observed here over the lactation period both in the presence and absence of white clover.

Our data indicate that lambing date can be delayed on paddocks containing endophyte-infected ryegrass (Table 1). The delay was consistent in each of the three years of the experiment and was more pronounced on mixed ryegrass/white clover pastures than on the pure ryegrass pastures. Extended gestation has been observed (Schmidt \& Osbom 1993) in other stock classes and with another endophyte species, but this is the first report involving sheep and the ryegrass endophyte. In our trial, ewes were mated shortly after a period of high pasture levels of endophyte-related toxins (unpub. data) and residual effects of those toxins could have affected animal responses. March levels of ergovaline and lolitrem B were up to $0.3 \mathrm{ppm}$ and $0.6 \mathrm{ppm}$ respectively in the trial paddocks. Levels of peramine reached average levels of $17.5 \mathrm{ppm}$ in February. Although peramine is an insect deterrent, it has been implicated in disorders in grazing animals (Pownall et al. 1993). However, the number of endophyte-associated chemicals is large and no definite conclusions can be drawn from analysis involving only a few of these. igure 2 Lamb liveweight changes averaged over 3 years from birth to weaning. Bars indicate 1sd 5\% for comparing weights.

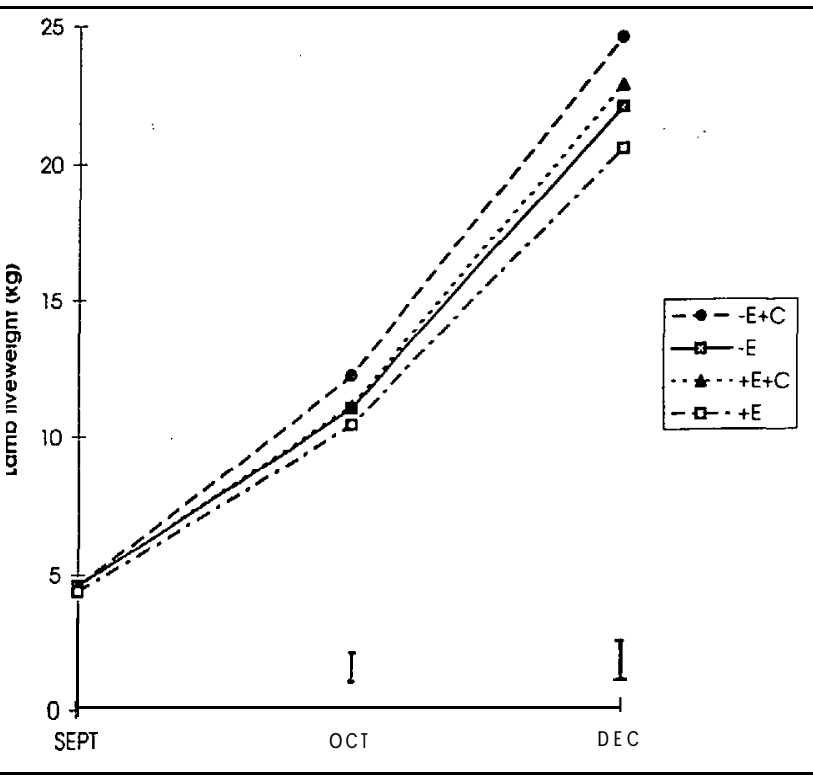

The observation that the presence of endophyte has a significant negative effect on early lamb growth can be explained only as a carry-over effect from the ewes. The normal pattern for endophyte activity (presence of hyphae and chemicals) in ryegrass plants is to increase from virtually unmeasurable levels in early-spring-to-high-levels-in-late-spring-Endophyte-is confined to the very base of the ryegrass plant early in the season and moves up seedheads by October/ November. Ewe milk production might be affected by the presence of endophyte. The presence of eridophyte has been reported to reduce serum prolactin levels, a precursor of milk production (Fletcher \& Barrell 1984).

Our data indicate that endophyte has little effect on ewe reproduction since there were no significant effects on either lamb birth weight or ewe conception rate.

The early lamb weight gains (Figure 2) matčch the weight changes in ewes between October and December, with gains highest for ewes on the $-\mathrm{E}+\mathrm{C}$ pastures followed by ewes on the $+E+C$ and $-E$ pastures with $+\mathrm{E}$ grazing ewes losing weight during lactation. Ewes have the capacity to mobilise body tissue during lactation (Geenty 1983), which may explain the body weight gain for the lambs suckling ewes grazing the $+\mathrm{E}$ pastures, while the ewes were losing weight.

The magnitude of endophyte effects depends on the environment, as has been established for tall fescue by Belesky et al. (1989) and Breen (1990) for perennial ryegrass. The endophyte appears to have little to 
contribute to the persistence of its host in the cool moist climate of southern New Zealand. With no beneficial effects of the endophyte observed and slightly lower pasture production in the presence of endophyte (Eerens et al. 1992), it can be argued that the endophyte is a host parasite in environments like southern New Zealand. Research suggests the endophyte is most beneficial to its host in stress conditions (Prestidge \& Ball 1993). Under those conditions and perhaps because of them, the level of toxin production appears to be highest. The different endophyte interactions with its host under different environmental conditions suggests that the results of our research can be applied only in areas with similar environments.

The results reported here and earlier (Eerens et al. 1992) question the need for endophyte-infected perennial ryegrass in areas with similar cool moist environments.

\section{REFERENCES}

Belesky, D.P.; Stringer, W.C.; Hill, N.S. 1989. Influence of endophyte and water regime upon tall fescue accessions. I. Growth characteristics. Annals of botany 63: 495-503.

Breen, J.P. 1990. Temperature and seasonal effects on expression of Acremonium lolii enhanced resistance to greenbug, Schizaphis graminum (Rondani) (Homoptera: Aphididae). Proceedings of the First International Symposium on Acremonium/Grass Interactions. (Eds.) Quisenberry \& Joost: 12-20.

Eerens, J.P.J.; Ryan, D.L.; Miller, K.B. 1992. The ryegrass endophyte in a cool moist environment. Proceedings of the NZ Grassland Association 54: 157-160.

Fletcher, L.R. 1983. Effects of presence of Lolium endophyte on growth rates of weaned lambs, growing on to hoggets, on various grasses. Proceedings of the NZ Grassland Association 44: 237-239.

Fletcher, L.R. 1993. Heat stress in lambs grazing ryegrass with different endophytes. Proceedings of the Second International Symposium on Acremonium/grass Interactions. Eds. Hume, Latch and Easton -114-1 18.

Fletcher, L.R.; Barrell, G.K. 1984. Reduced liveweight gains and serum prolactin levels in hoggets grazing ryegrass containing Lolium endophyte. NZ veterinary journal 32: 139- 140.
Fletcher, L.R.; Harvey, I.C. 1981. An association of a Lolium endophyte with ryegrass staggers. NZ veterinary journal 29: 185. 186.

Geenty, K.G. 1983. Pasture feeding for maximum lamb growth. In: Familton A.S. (Ed.) Lamb growth, Technical Handbook. Animal Industries Workshop June-July 1983 Lincoln College. pp: 105-1 10.

Latch, G.C.M.; Hunt, W.F.; Musgrave, D.R. 1985. Endophytic fungi affect growth of perennial ryegrass. $N Z$ journal of agricultural research 28 : 165-168.

Pownall, D.B.; Lucas, R.J.; Familton, A.S.; Love, B.G.; Fletcher, L.R. 1993. Endophyte associated mycotoxins and diarrhoea in lambs. Proceedings of the Second International Symposium on Acremonium/grass Interactions Eds. Hume, Latch and Easton 132-134.

Prestidge, R.A.; Ball, O.J-P. 1993. The role of endophytes in alleviating plant biotic stress in New Zealand. Proceedings of the Second International Symposium on Acremonium/grass Interactions: Plenary papers Eds. Hume, Latch and Easton 141151.

Prestidge, R.A.; Pottinger, R.P.; Barker, G.M. 1982. An association of Lolium endophyte with ryegrass resistance to Argentine stem weevil. Proceedings of the 35th NZ Weed and Pest Control Conference: 119-122.

Schmidt, S.P.; Osbom, T.G. 1993. Effects of endophyteinfected tall fescue on animal performance. Agriculture, ecosystems and environments 44: 233262.

Stevens, D.R.; Hickey, M.J. 1990. Effects of endophytic ryegrass on the production of ryegrass/white clover pastures. Proceedings of the First International Symposium on Acremonium/Grass Interactions. (Eds.) Quisenberry \& Joost: 58-61.

Sutherland, B.L.; Hoglund, J.H. 1989. Effect of endophyte (Acremonium lolii) on performance of associated white clover and subsequent crops. Proceedings of the NZ Grassland Association 50: 265-269.

Widdup, K.H.; Ryan, D.L. 1992. Forage potential of wild populations of perennial ryegrass collected from southern New Zealand farms. Proceedings of the NZ Grassland Association 54: 161-165. 